\title{
Metastable Transitions in Pyridine and Pyridine Derivatives
}

\author{
Th. M. El-Sherbini
}

Physics Department, Faculty of Science, Cairo University, Egypt

M. D. Migahed and A. M. Shehap

Physics Department, Faculty of Science, University of Mansoura, Egypt

Z. Naturforsch. 36 a, 1115-1117 (1981); received June 1, 1981

The kinetic energy released in metastable transitions in pyridine, $2,3,4$ acetylpyridine and 2, 3, 4 aminopyridine differs for the different isomers. This indicates that the dissociation pathway of these compounds depends on the position of the nitrogen atom in the isomer.

\section{Introduction}

Metastable transitions observed in a mass spectrometer provide useful information about fragmentation pathways in molecules and hence help in elucidating the molecular structure $[1,2]$.

A double focusing mass spectrometer offers two techniques by which metastable peaks can be studied. The first one is the defocusing technique [3] which is used to detect metastable ions dissociating in the first field free region between the ion source and the magnetic analyzer. The second technique is the DADI technique [4] which is suitable for studying metastable ions dissociating in the second field free region between the magnet and the electrostatic sector.

We have applied both techniques in determining the kinetic energy released in the dissociation of pyridine, 2, 3, 4 acetylpyridine and 2, 3, 4 aminopyridine after electron impact. The aim of the work is to study the fragmentation pathways of these molecules and to show the effect of the positions of the substituents in the various isomers on the kinetic energy released.

\section{Experimental}

The apparatus and the experimental procedure were described elsewhere [ $5-7]$. In brief, measurements of metastable peaks were made using a Varian MAT CH5 reversed Nier-Johnson double focusing mass spectrometer. The standard normal operating conditions were: accelerating voltage $3 \mathrm{kV}$; electrostatic sector voltage $539 \mathrm{~V}$; ionizing

Reprint requests to Dr. Th. M. El-Sherbini, Physics Department Faculty of Science, Cairo University, Egypt. electron energy $70 \mathrm{eV}$; total emission current $1 \mathrm{~mA}$; resolving power ca. 3000 . The ion source pressure was varied over the range $1 \times 10^{-7}-1 \times 10^{-5}$ torr and the source temperature was $130^{\circ} \mathrm{C}$. The recordings of the metastable spectra were carried out using the usual accelerating voltage [8] and electrostatic sector voltage [9] scan procedure. The voltage was determined with a digital voltmeter. The high and sector voltages can be varied in steps of 0.001 and $0.1 \mathrm{~V}$, respectively. Each peak was recorded on a potentiometer recorder at least three times.

The metastable peak width at half-height was used to determine the characteristic values of the kinetic energy released $[6,7]$. The energy values were reproducable to within $\pm 0.005 \mathrm{eV}$.

\section{Results and Discussion}

The most intense metastable transitions observed for the molecular and fragment ions of pyridine, acetylpyridine isomers aminopyridine isomers are listed in Tables 1, 2 and 3 respectively. The tables contain also the kinetic energy released for the various transitions in the first and second field free regions together with the peak shapes.

Most of the metastable peaks have a gaussian shape while only few peaks have a flat topped shape. In some transitions the released kinetic energy obtained from the defocusing technique differs from that obtained from the DADI technique. This can be attributed to the different ion lifetimes which lead to different internal energies for dissociation in the first and second field-free regions [7].

For 2-acetylpyridine the strongest transition leading to large kinetic energy is the one resulting from the elimination of carbon monoxide from the molecular ion (see Table 2). This has been explained 
Table 1. Kinetic energy released in metastable transitions in pyridine ( $\mathrm{G}=$ Gaussian; $\mathrm{F}=$ flat-topped).

\begin{tabular}{llll}
\hline Metastable transition & $\begin{array}{c}\text { Peak } \\
\text { Shape }\end{array}$ & \multicolumn{2}{l}{$T(\mathrm{eV})$} \\
\cline { 4 - 5 } & & Defocusing & DADI \\
\hline $\mathrm{C}_{5} \mathrm{H}_{5} \mathrm{~N}^{+} \rightarrow \mathrm{C}_{5} \mathrm{H}_{4} \mathrm{~N}^{+}+\mathrm{H}$ & $\mathrm{G}$ & 0.135 & 0.246 \\
$\mathrm{C}_{5} \mathrm{H}_{5} \mathrm{~N}^{+} \rightarrow \mathrm{C}_{4} \mathrm{H}_{4}^{+}+\mathrm{HCN}$ & $\mathrm{G}$ & 0.019 & 0.020 \\
$\mathrm{C}_{5} \mathrm{H}_{4} \mathrm{~N}^{+} \rightarrow \mathrm{C}_{5} \mathrm{H}_{3} \mathrm{~N}^{+}+\mathrm{H}$ & $\mathrm{G}$ & & 0.006 \\
$\mathrm{C}_{5} \mathrm{H}_{4} \mathrm{~N}^{+} \rightarrow \mathrm{C}_{4} \mathrm{H}_{3}^{+}+\mathrm{HCN}$ & $\mathrm{G}$ & 0.028 & 0.029 \\
$\mathrm{C}_{4} \mathrm{H}_{4}^{+} \rightarrow \mathrm{C}_{4} \mathrm{H}_{3}^{+}+\mathrm{H}$ & $\mathrm{G}$ & 0.117 & 0.398 \\
$\mathrm{C}_{4} \mathrm{H}_{4}^{+} \rightarrow \mathrm{C}_{4} \mathrm{H}_{2}^{+}+\mathrm{H}_{2}$ & $\mathrm{~F}$ & & 0.407 \\
$\mathrm{C}_{4} \mathrm{H}_{3}+\rightarrow \mathrm{C}_{4} \mathrm{H}_{2}^{+}+\mathrm{H}^{+}$ & $\mathrm{G}$ & & 0.069 \\
\hline
\end{tabular}

by assuming that the pyridine nitrogen atom induces the skeletal rearrangement process [10]. The peak observed from this reaction is much broader than the usual "metastable peak" and has a pronounced dip in its centre.
Although the elimination of $\mathrm{CO}$ from the molecular ion is the predominating reaction in case of 2 -acetylpyridine, it is absent in case of 3 and 4 acetylpyridine. The C-C bond fission reaction (first reaction in Table 2) is the most probable one in the case of 3 and 4 acetylpyridine, in agreement with previous results [10]. It is therefore concluded that the decomposition of the molecule depends on the position of the substituent with respect to the nitrogen atom. However, the amount of energy released from the C-C bond fission for the three isomers is $0.03 \mathrm{eV}$ on the average, indicating that the position of the substituent has no effect on the kinetic energy released in this reaction.

Most of the metastable transitions in aminopyridine isomers occur in the second field free region (see Table 3 ). Table 3 and the intensities of

Table 2. Kinetic energy released in metastable transitions in acetylpyridine isomers $(\mathrm{D}=$ dish topped).

\begin{tabular}{|c|c|c|c|c|c|c|c|c|c|c|c|}
\hline \multicolumn{3}{|c|}{ Metastable transition } & \multicolumn{9}{|c|}{$T(\mathrm{eV})$} \\
\hline & & & \multicolumn{3}{|c|}{ 2-acetylpyridine } & \multicolumn{3}{|c|}{ 3-acetylpyridine } & \multicolumn{3}{|c|}{ 4-acetylpyridine } \\
\hline & & & $\begin{array}{l}\text { Peak } \\
\text { shape }\end{array}$ & $\begin{array}{l}\text { Defocus- } \\
\text { ing }\end{array}$ & DADI & $\begin{array}{l}\text { Peak } \\
\text { shape }\end{array}$ & $\begin{array}{l}\text { Defocus- } \\
\text { ing }\end{array}$ & DADI & $\begin{array}{l}\text { Peak } \\
\text { shape }\end{array}$ & $\begin{array}{l}\text { Defocus- } \\
\text { ing }\end{array}$ & DADI \\
\hline \multicolumn{3}{|c|}{$\mathrm{C}_{7} \mathrm{H}_{7} \mathrm{NO}^{+} \rightarrow \mathrm{C}_{6} \mathrm{H}_{4} \mathrm{NO}^{+}+$} & G & 0.029 & 0.037 & G & 0.025 & 0.024 & G & 0.024 & 0.020 \\
\hline \multicolumn{3}{|c|}{$\mathrm{C}_{7} \mathrm{H}_{7} \mathrm{NO}^{+} \rightarrow \mathrm{C}_{6} \mathrm{H}_{7} \mathrm{~N}^{+}+$} & D & 0.618 & 0.484 & & & & & & \\
\hline \multirow{2}{*}{\multicolumn{2}{|c|}{$\begin{array}{l}\mathrm{C}_{7} \mathrm{H}_{7} \mathrm{NO}^{+} \rightarrow \mathrm{C}_{5} \mathrm{H}_{5} \mathrm{~N}^{+} \\
\mathrm{C}_{6} \mathrm{H} \mathrm{NO}^{+} \rightarrow \mathrm{C}_{6} \mathrm{H}_{2} \mathrm{NO}^{+}\end{array}$}} & $+\mathrm{CH}_{2} \mathrm{CO}$ & G & 0.020 & 0.009 & & & & & & \\
\hline & & $+\mathrm{H}$ & G & & 0.156 & G & & 0.079 & G & & 0.075 \\
\hline \multicolumn{2}{|c|}{$\begin{array}{l}\mathrm{C}_{6} \mathrm{H}_{4} \mathrm{NO}^{+} \rightarrow \mathrm{C}_{6} \mathrm{H}_{3} \mathrm{NO}^{+} \\
\mathrm{C}_{6} \mathrm{H}_{4} \mathrm{NO}^{+} \rightarrow \mathrm{C}_{4} \mathrm{NO}^{+}\end{array}$} & $+\mathrm{C}_{2} \mathrm{H}_{4}$ & G & 0.016 & 0.012 & G & 0.027 & 0.021 & G & 0.027 & 0.038 \\
\hline $\mathrm{C}_{6} \mathrm{H}_{7} \mathrm{~N}^{+}$ & $\begin{array}{l}\rightarrow \mathrm{C}_{6} \mathrm{H}_{6} \mathrm{~N}^{+} \\
\rightarrow \mathrm{C}_{5} \mathrm{H}_{6}^{+}\end{array}$ & $\begin{array}{l}+\mathrm{H} \\
+\mathrm{HCN}\end{array}$ & G & & 0.265 & & & & & & \\
\hline $\mathrm{C}_{5} \mathrm{H}_{5} \mathrm{~N}^{+}$ & $\rightarrow \mathrm{C}_{5} \mathrm{H}_{4} \mathrm{~N}^{+}$ & $+\mathrm{H}$ & $\vec{G}$ & 0.168 & 0.269 & G & & 0.197 & G & & 0.187 \\
\hline $\mathrm{C}_{5} \mathrm{H}_{5} \mathrm{~N}^{+}$ & $\rightarrow \mathrm{C}_{5} \mathrm{H}_{3} \mathrm{~N}^{+}$ & $+\mathrm{H}_{2}$ & G & & 0.151 & & & & & & \\
\hline $\mathrm{C}_{5} \mathrm{H}_{5} \mathrm{~N}^{+}$ & $\rightarrow \mathrm{C}_{4} \mathrm{H}_{4}^{+}$ & $+\mathrm{HCN}$ & G & 0.038 & 0.016 & G & 0.044 & 0.026 & $\mathrm{G}$ & 0.024 & 0.016 \\
\hline $\mathrm{C}_{5} \mathrm{H}_{4} \mathrm{~N}^{+}$ & $\rightarrow \mathrm{C}_{4} \mathrm{H}_{3}^{+}$ & $+\mathrm{HCN}$ & G & 0.029 & 0.034 & G & 0.061 & 0.030 & $\mathrm{G}$ & 0.041 & 0.015 \\
\hline $\mathrm{C}_{4} \mathrm{H}_{4}^{+}$ & $\rightarrow \mathrm{C}_{4} \mathrm{H}_{3}{ }^{+}$ & $+\mathbf{H}$ & $\mathbf{G}$ & 0.219 & 0.101 & G & 0.155 & 0.137 & G & 0.138 & 0.144 \\
\hline $\mathrm{C}_{4} \mathrm{H}_{4}+$ & $\rightarrow \mathrm{C}_{4} \mathrm{H}_{2}{ }^{+}$ & $+\mathrm{H}_{2}$ & $\mathbf{F}$ & & 0.409 & & & & & & \\
\hline
\end{tabular}

Table 3. Kinetic energy released in metastable transitions in aminopyridine isomers.

\begin{tabular}{|c|c|c|c|c|c|c|c|c|c|c|c|}
\hline \multicolumn{3}{|c|}{ Metastable transition } & \multicolumn{9}{|c|}{$T(\mathrm{eV})$} \\
\hline & & & \multicolumn{3}{|c|}{ 2-aminopyridine } & \multicolumn{3}{|c|}{ 3-aminopyridine } & \multicolumn{3}{|c|}{ 4-aminopyridine } \\
\hline & & & $\begin{array}{l}\text { Peak } \\
\text { shape }\end{array}$ & $\begin{array}{l}\text { Defocus- } \\
\text { ing }\end{array}$ & DADI & $\begin{array}{l}\text { Peak } \\
\text { shape }\end{array}$ & $\begin{array}{l}\text { Defocus- } \\
\text { ing }\end{array}$ & DADI & $\begin{array}{l}\text { Peak } \\
\text { shape }\end{array}$ & $\begin{array}{l}\text { Defocus- } \\
\text { ing }\end{array}$ & DADI \\
\hline $\begin{array}{l}\mathrm{C}_{5} \mathrm{H}_{6} \mathrm{~N}_{2}+ \\
\mathrm{C}_{5} \mathrm{H}_{6} \mathrm{~N}_{2}^{+} \\
\mathrm{C}_{5} \mathrm{H}_{5} \mathrm{~N}_{2}^{+} \\
\mathrm{C}_{5} \mathrm{H}_{5} \mathrm{~N}_{2}^{+} \\
\mathrm{C}_{4} \mathrm{H}_{5} \mathrm{~N}^{+} \\
\mathrm{C}_{4} \mathrm{H}_{5} \mathrm{~N}^{+} \\
\mathrm{C}_{4} \mathrm{H}_{5} \mathrm{~N}^{+} \\
\mathrm{C}_{3} \mathrm{H}_{4}^{+} \\
\mathrm{C}_{4} \mathrm{H}_{4}^{+} \\
\mathrm{C}_{3} \mathrm{H}_{2} \mathrm{~N}^{+}\end{array}$ & $\begin{array}{l}\rightarrow \mathrm{C}_{5} \mathrm{H}_{5} \mathrm{~N}_{2}+ \\
\rightarrow \mathrm{C}_{4} \mathrm{H}_{5} \mathrm{~N}_{2}^{+} \\
\rightarrow \mathrm{C}_{5} \mathrm{H}_{4} \mathrm{~N}_{2}^{+} \\
\rightarrow \mathrm{C}_{4} \mathrm{H}_{4} \mathrm{~N}^{+} \\
\rightarrow \mathrm{C}_{4} \mathrm{H}_{4} \mathrm{~N}^{+} \\
\rightarrow \mathrm{C}_{3} \mathrm{H}_{5}^{+} \\
\rightarrow \mathrm{C}_{3} \mathrm{H}_{4}^{+} \\
\rightarrow \mathrm{C}_{3} \mathrm{H}_{3}^{+} \\
\rightarrow \mathrm{C}_{4} \mathrm{H}_{2}^{+} \\
\rightarrow \mathrm{C}_{3} \mathrm{HN}^{+}\end{array}$ & $\begin{array}{l}+\mathrm{H} \\
+\mathrm{HCN} \\
+\mathrm{H} \\
+\mathrm{HCN} \\
+\mathrm{H} \\
+\mathrm{CN} \\
+\mathrm{HCN} \\
+\mathrm{H} \\
+\mathrm{H}_{2} \\
+\mathrm{H}\end{array}$ & $\begin{array}{l}\mathbf{G} \\
\mathbf{F} \\
\mathbf{G} \\
\mathbf{F} \\
\mathbf{G} \\
\mathbf{G} \\
\mathbf{F} \\
\mathbf{F}\end{array}$ & 0.078 & $\begin{array}{l}0.079 \\
0.137 \\
0.029 \\
0.241 \\
0.034 \\
0.117 \\
\\
0.408\end{array}$ & $\begin{array}{l}\mathrm{G} \\
\mathrm{G} \\
\mathrm{G} \\
\mathrm{G} \\
\mathrm{F} \\
\mathrm{G} \\
\mathrm{G} \\
\mathrm{G}\end{array}$ & $\begin{array}{l}0.340 \\
0.111\end{array}$ & $\begin{array}{l}0.283 \\
0.115 \\
0.106 \\
0.031 \\
0.053 \\
0.020 \\
0.024\end{array}$ & $\begin{array}{l}\mathrm{G} \\
\mathrm{G} \\
\mathrm{G} \\
\mathrm{G} \\
\mathrm{F} \\
\mathrm{F} \\
\mathrm{G} \\
\mathrm{F} \\
\mathrm{G}\end{array}$ & $\begin{array}{l}0.242 \\
0.212\end{array}$ & $\begin{array}{l}0.303 \\
0.137 \\
0.103 \\
0.032 \\
0.130 \\
0.050 \\
0.053\end{array}$ \\
\hline
\end{tabular}


the peaks suggest that the reaction involving the separation of a hydrogen atom from the molecular ions is a favourable reaction in 3- and 4-aminopyridine, while that involving the separation of a hydrogen molecule is favourable in 2 -aminopyridine and is absent in case of 3 - and 4-aminopyridine. This indicates that the dissociation pathways for some ions depends on the position of the nitrogen atom in the different isomers.

It is interesting to notice from Tables 1,2 and 3 that, although similar transitions in the three compounds do not lead to the same kinetic energy, the formation of $\mathrm{C}_{4} \mathrm{H}_{2}^{+}(m / e=50)$ from the decomposition of the fragment ion $\mathrm{C}_{4} \mathrm{H}_{4}^{+}((m / e=52)$ is accompanied by a kinetic energy release of about

[1] J. L. Holmes, J. K. Terlouw, P. C. Vijfhuizen, and C. A'Campo, Org. Mass Spectrom. 14, 204 (1979).

[2] A. Maquestiau, R. Flammang, G. L. Glish, J. A Laramee, and R. G. Cooks, Org. Mass Spectrom. 15, 131 (1980).

[3] M. A. Baldwin and F. W. McLafferty, Int. J. Mass Spectrom. Ion Phys. 12, 86 (1973).

[4] A. Venema, N. M. M. Nibbering, K. H. Maurer, and U. Rapp, Int. J. Mass Spectrom. Ion Phys. 17, 84 (1975).
$0.408 \mathrm{eV}$ in pyridine, acetylepyridine and aminopyridine. We therefore conclude that the $\mathrm{C}_{4} \mathrm{H}_{4}{ }^{+}$ fragment ion in the three compounds has the same structure.

In conclusion we can say that in general the position of the nitrogen atom in pyridine, acetylpyridine and aminopyridine isomers influences the distribution of the internal energy of the metastable ions. The decay of these ions leads to the observed spread in the kinetic energies of the product ions.

\section{Acknowledgement}

We acknowledge the continuous support of Professor Dr. M. El-Nadi during this work.

[5] Th. M. El-Sherbini, M. D. Migahed, and A. M. Shehap, Proc. Math. Phys. Soc. (Egypt) 44, 167 (1977).

[6] M. D. Migahed, A. M. Shehap, and Th. M. El-Sherbini, Proc. Math. Phys. Soc. (Egypt) 44, 173 (1977).

[7] M. D. M. Migahed and F. H. Abd El-Kader, Int. J. Mass Spectrom. Ion Phys. 28, 225 (1978)

[8] K. R. Jennings, J. Chem. Phys. 43, 4176 (1965)

[9] C. Reichert, R. E. Fraas, and R. W. Kiser, Int. J. Mass Spectrom. Ion Phys. 5, 457 (1970).

[10] M. D. Migahed, A. I. Helal, and S. B. El-Kholy, Org. Mass Spectrom. 7, 1423 (1973). 